INDEPENDENT JOURNAL OF MANAGEMENT \& PRODUCTION (IJM\&P)

http://www.ijmp.jor.br

v. 12, n. 6, Special Edition ISE, S\&P - November 2021

ISSN: 2236-269X

DOI: 10.14807/ijmp.v12i6.1760

\title{
DEVELOPMENT OF THE INSTITUTIONAL ACCOUNTING FOR THE NEEDS OF FINANCIAL REGULATION: EXPERIENCE IN THE AGRICULTURAL SECTOR OF UKRAINE
}

\author{
Nataliia Semenyshena \\ Western Ukrainian National University; \\ State Agrarian and Engineering University in Podilya, Ukraine \\ E-mail: natviksem@gmail.com.br \\ Oksana Radchenko \\ Institute of Agrarian Economics, Ukraine \\ E-mail: ox73@ukr.net \\ Andrii Zelenskyi \\ State Agrarian and Engineering University in Podilya, Ukraine \\ E-mail: zelenskiy2306@gmail.com \\ Nadiia Khocha \\ Ivan Franko National University of Lviv, Ukraine \\ E-mail:nadiya.khocha@Inu.edu.ua \\ Ulyana Pelekh \\ Ivan Franko National University of Lviv, Ukraine \\ E-mail: ulyana.pelekh@lnu.edu.ua
}

Submission: 8/9/2021 Accept: 10/6/2021

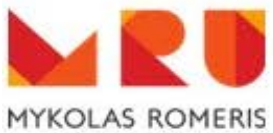
UNIVERSITY

\section{ABSTRACT}

The study of the accounting environment was conducted and proposals for improving its theory for the needs of the macro-level of management from the standpoint of institutional theories were formed. A working hypothesis is proposed on the dependence of data collection methods for financial regulation, the formation of a development strategy for the industry, the selection of the Structure of programs of state support for goods and services, and it is tested on examples of budgetary financial regulation of the agricultural sector of Ukraine. For this, the existing scientific approach and practice of information support of financial support were analysed using examples of budget programs in the agricultural sector of the economy, determination of the state and ambushes of its further development in relation to the financial condition of agricultural enterprises, the level of their accounting and financial reporting, and, accordingly, the awareness 
of managers concerning participation in budget programs, submission of applications that takes budget support and its effective use. The analysis of indicators in the effectiveness of budget programs is carried out in order to disclose the relationship between accounting and macroeconomic indicators in the development of the agricultural sector of Ukraine. The methodological approach to determining the effectiveness of budgetary support for the development of the agro-industrial complex is generalized, a comparative assessment of the effectiveness of various programs of state financial support for agricultural commodities and production sites is carried out and statistical material on the state of agriculture is processed the Impact of budgetary support on the formation of financial indicators in the agricultural sector was determined. Proposals were provided for the concentration of state financial resources on the Key Program of Budgetary Support for the development of the agricultural sector and improvement of the organizational mechanism functioning of the system of budgetary subsidies for agricultural goods. The main indicators of monitoring the effectiveness of state programs to support the agricultural sector have been outlined and proposals are given for improving the information support of this process, accounting tools, financial and budgetary reporting. Recommendations are given for the concentration of state financial resources on the Key Program of Budgetary Support for the development of the agricultural sector and the improvement of the organizational mechanism of functioning of the system of budget subsidies in connection with the achieved financial indicators of activity of the commodity producers formed in the accounting and information system.

Keywords: Institutional accounting; institutional theory; agrarian budget; state budget programs; financial regulation; financial reporting; Ukraine

\section{INTRODUCTION}

In the context of global information processes, the functioning and improvement of accounting is carried out as a result of accounting for the effectiveness and selection of consistent economic laws, with the help of which it is possible to improve the theoretical, regulatory and methodological support of the accounting and economic processes directly. This process is most fully revealed in the institutional theory.

It, as a kind of interdisciplinary research platform, considering the social component, makes it possible to identify and systematize the factors influencing the use of accounting information in the process of financial regulation on the example of making budget decisions. 
DOI: $10.14807 /$ ijmp.v12i6.1760

The rules and standards for the formation and collection of information for the needs of public administration and financial regulation of sectors of the economy are important.

\section{LITERATURE REVIEW}

Accounting theory and its relationship with public administration practice is currently at the centre of scientific discussions. Regarding the completeness of considering the needs of management at the level of state financial regulation, the range of studies is quite wide. Scott (2005) argues that institutional theory fosters a combination of historical and comparative research and provides conceptual tools to capture and interpret the extraordinary diversity of organizations across time and space.

Covaleski and Dirsmith (1988) investigated accounting systems for different "link of services” in budgetary institutions, using an institutional perspective to expand the conceptual framework for accounting for power and division of responsibility. Ridder, Bruns \& Spier (2005) note that in Germany, local governments, facing a growing tension between declining financial security and increasing demands for responsible management, are initiating changes in the accounting system, introducing accrual accounting and performance budgeting.

Pozzoli and Ranucci (2013) described the process of introducing accounting harmonization in local governments in Italy.

Khadaroo (2005) reviewed the impact of institutional theory on the accounting standard setting process under the UK Private Finance Initiative. The influence of institutional factors on the financial reporting standards of the countries of Central and Eastern Europe, according to the findings of Albu, Albu and Gray (2020), is manifested in benefits at the level of countries with lower quality of institutions, but with more available organizational mechanisms than in countries with stronger institutions, which is due to higher expectations from IFRS in others.

Scapens and Varoutsa (2010) examined accounting in inter-organizational relations from an institutional theory perspective, noting that in recent years this theory has had a great influence on research in various fields of social sciences, including economics, sociology, political science, organizational theory, public administration, as well as accounting.

Nurunnabi (2015) uncovered the reasons for the tension between political-institutional factors and accounting regulation in the institutional theory evolving through the use of tools. The study contributes to understanding the influence of political forces on the information environment of a company in a developing one. The assessment of changes in management accounting in accordance with the approaches of institutional theory was carried out by 
DOI: $10.14807 /$ ijmp.v12i6.1760

Guerreiro, Pereira and Frezatti (2006), as well as Ribeiro and Scapens (2006) for disclosing two directions of institutional research: "old institutional economics" and "new institutional sociology".

Information problems, viewed through the prism of institutional theory, according to Greenwood, Suddaby and Hinings (2002), challenge rational theories of market valuation, generating rhetorical theory in management and communications. Agyekum and Singh (2018) investigated how institutional and prospect theory technologies are changing accounting processes. Guerreiro, Lima and Craig (2021) highlighted that institutional theory has the ability to provide an in-depth understanding of the change processes associated with the adoption and implementation of international accounting standards by countries and organizations.

Yapa \& Guah (2012) analyse how a new public financial management system should consider the efficiency and effectiveness of the public sector through electronic accrual accounting for greater transparency in public sector accounting. Zimmerman, Fogarty \& Jonas (2017) pose the question of whether accounting is generally an applied discipline through institutional information valuation theory.

The allocation of institutional in modern accounting concepts (theory and methodology) was carried out by Chaikovskaya (2007), pointing to the framework of changes in the institutional environment and state economic policy that affects the institutional factors of financial reporting. Pankov, Kozhukhov and Peshekhonov (2008) revealed an institutional approach to accounting theory based on an analysis of international and domestic research. Sannikova (2008) proposes to overcome the crisis of accounting theory by applying the institutional concept of accounting.

Polenova (2012) points out that the updating of tools in the development of scientific and applied research in the field of accounting is due to the use of new theoretical developments in economic theory. Sidorova (2013) to the question of the accounting paradigm indicates that the main object of study of this theory is the accounting institution.

According to the research of Ukrainian scientists, based on the sociality of accounting as a science that develops under the influence of business, today it is not only taking into account economic activities, but also an analytical doctrine, including all stages from planning and forecasting activities to monitoring the effectiveness of individual operations and all activities with the calculation of the consequences of making managerial decisions and is inevitably influenced by various institutions. 
DOI: 10.14807/ijmp.v12i6.1760

The foundations of the domestic institutional theory of accounting were formed by Zhuk (2014), he revealed the role and significance of the accounting component of economic science, analysed the relationship between the evolution of accounting and economic theories, and formulated the foundations of the institutional theory of accounting.

Semenyshena et al. (2020) revealed realities of institutional approach to the development of accounting, noting that the development of accounting is directly proportional to the development of economic science, the application of institutional theory in practice will allow for an effective change of institutions in order to achieve the set strategic goals.

Vysochan and Yahvak (2017) explored institutionalism in contemporary domestic accounting theory through historical origins and genesis. Kantsurov (2014) investigated the institutional segmentation of the accounting institution. Shukalovych (2014) revealed the essence of information support for internal institutions of vertical integration in agribusiness.

Radchenko and Koval (2016) defined accounting support for the management of financial activities of agricultural enterprises, which discloses the essence, principles and methodology of this process.

Mishchenko (2019) described the development of the institutional mechanism of state support for the agricultural sector of Ukraine. Thus, the institutional approach provides the key to a comprehensive understanding of the theory and practice of accounting and communication links. The task is to study the development of the institutional theory of accounting for the needs of financial regulation on the example of the agricultural sector of Ukraine.

The purpose of the article is to determine the requirements for the accounting theory for the needs of financial regulation in terms of budgetary financing of the agricultural sector of Ukraine by institutional analysis of factors influencing the quality of information, the structure of budget programs, indicators for monitoring their effectiveness.

\section{METHODOLOGY}

In this study, the methods of financial theory (composition and decomposition) were used in determining the category of budget expenditure management, methods of comparison and statistical analysis for disclosing the components of budget programs, determination of dependencies and efficiency when comparing methods of information display of the control object of the budget process, the formalization method for the selection of evaluation indicators the effectiveness of managing the budgetary process on the basis of institutions, the method of analysing hierarchies for disclosing the mechanism of operation of accounting standards in the 
DOI: 10.14807/ijmp.v12i6.1760

agricultural sector and expert assessments to study foreign experience in the synergy of accounting and information support for managing budget expenditures.

The article also used the following methods: dialectical, abstract and logical (for theoretical research and the formation of conclusions); statistical and monographic (for analysing the current state of budget support); historical and logical (to determine the problems and prospects for the further development of budget regulation through established joint institutions with information support.

The general positive characteristics of the institutional accounting theory include a wide range of research methods that are not just interdisciplinary in nature, but also include an organic approach, especially. At the same time, the application of the latter is rather complicated, because the characteristics of the organic model are difficult to formalize and represent in numerical terms. Therefore, there is a need for the development of research in this direction.

The study was based on the hypothesis of the dependence of data collection methods for financial regulation, the formation of industry development strategy, selection of the structure of state support programs for commodity producers, that is, the quality of budget support directly depends on the selected information methods, in including accounting management.

In this context, we share the opinion of researchers, the main reasons for the formation of the institutional theory of accounting are: the existence of interdisciplinary links between accounting and economic theory (Polenova, 2012); adaptation of economic methods and tools to the practice of accounting in order to solve problem situations, the need for separate approaches in accordance with accounting practice, focusing on the theory of institutionalism (Zhuk, 2014).

The sources of data are the official open sites of the State Statistics of Ukraine and the OECD, the State Treasury, the National Bank of Ukraine, regulatory documents on the regulation of agricultural development - the Law of Ukraine on State Support of Agriculture (2004), the annual Laws on the State Budget, as well as the Agriculture Development Strategy Ukraine (2012). 
ISSN: 2236-269X

DOI: $10.14807 /$ ijmp.v12i6.1760

\section{RESULTS}

An important direction of economic research is the creation of an institutional theory of accounting, within the framework of which many important scientific problems associated with state regulation of financial resources of the sectors of the economy can be solved. As part of the study, it is necessary to determine what exactly the needs of government regulation. First of all, such regulation provides for budgetary support for the sectors of the economy.

Figure 1 shows data on the dynamics of State budget expenditures for individual sectors in 2013-2020.

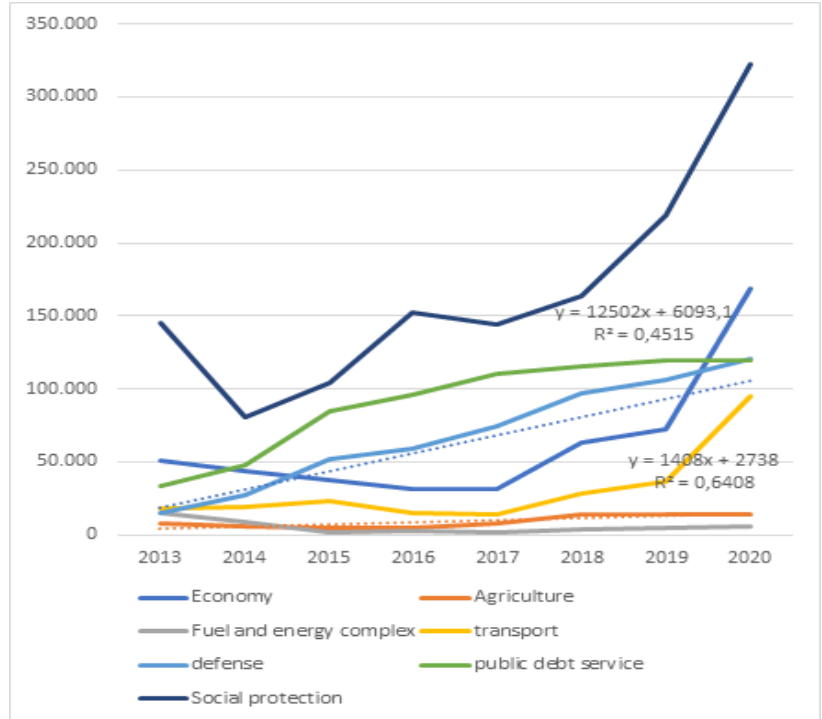

Figure 1: Dynamics of State budget expenditures on certain sectors in 2013-2020, UAH billion

Source: Calculated according to the data of the State Treasury of Ukraine. URL: https://www.treasury.gov.ua/ua; Radchenko etc. (2021)

The presented data indicate that the functional division of expenditures makes it possible to reveal the proportions in the distribution of budgetary funds.

Thus, for the period under review, the highest level of expenditures is observed in the field of social protection - 24-32\% of total budget expenditures. Further in descending order are education, national functions, health care, economic activity, security, and defence. From such a structure, it follows that in Ukraine the main source of budget consumption is the social sphere. Financing of economic activity does not exceed $10 \%$ of the total expenditures of the consolidated budget.

Budget financing and its size are largely determined by the state of the economy. In order to stimulate the formation of financial resources of manufacturing industries, a certain level of their budgetary support must be achieved, which is based on the effect that the industry 
DOI: $10.14807 /$ ijmp.v12i6.1760

brings to national benefits. The share of the budget for economic activity in 2020 is $13.19 \%$, while in 2019. - 16.75\%, in $2011-13.4 \%$.

The transport sector is better financed from the sectors of the economy - expenses on them increased by $150 \%$, and on the agricultural sector - by $86 \%$. But in general, the growth in recent years of spending on the economy and its industries has practically not occurred.

Fiscal regulation, given the possibility of spending combinations, has significant potential to influence investment and consumer demand, as well as real GDP growth. That is, a change in the distribution of budget expenditures entails the necessary shifts in the sectoral structure of social production.

For an effective policy of budgetary regulation, constant monitoring of the state of industries and their contribution to GDP is required.

Dynamics of the volume and structure of gross domestic product by type of economic activity for 2013-2020 was shown in Figure 2.

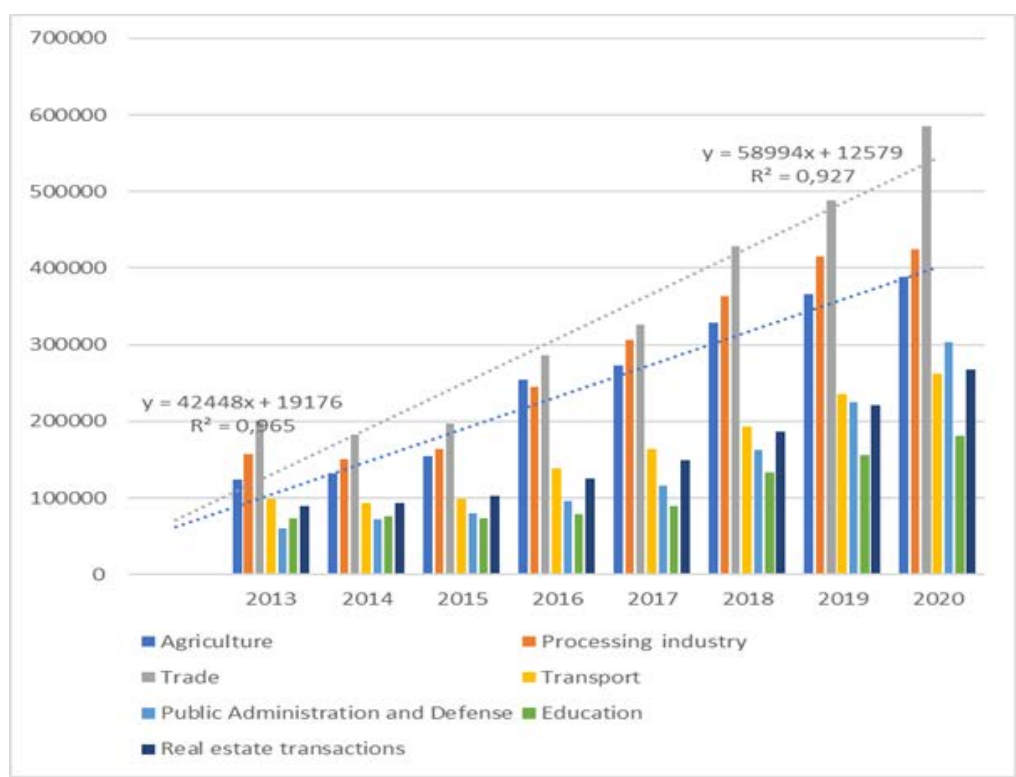

Figure 2: Dynamics of the volume and structure of gross domestic product by type of economic activity (in prices of the previous year) for 2013-2020, billion UAH Source: Calculated according to the State Statistics Service of Ukraine http://ukrstat.gov.ua/

Analysis of trends by industry shows that the largest contribution to GDP in recent years has been made by the agricultural sector. According to 2013-2020 with a confidence level of 96.5\%, it can be predicted that in the next 3 years, the annual growth of GDP produced by it will amount to UAH 40.4 billion.

Thus, we examined the indicators used by the management to implement financial regulation. The relationship with accounting data can be traced in the fact that statistically 
DOI: 10.14807/ijmp.v12i6.1760

collected and processed information "Indicators of enterprises, grouped by special aggregations provided for in Regulation (EC) No. 251/2009 of 11.03.2009 on structural statistics of enterprises”, data for 2013-2019 are shown in Fig. 3. It should be noted that there is practically no difference in the results of different calculation methods (institutional and functional).

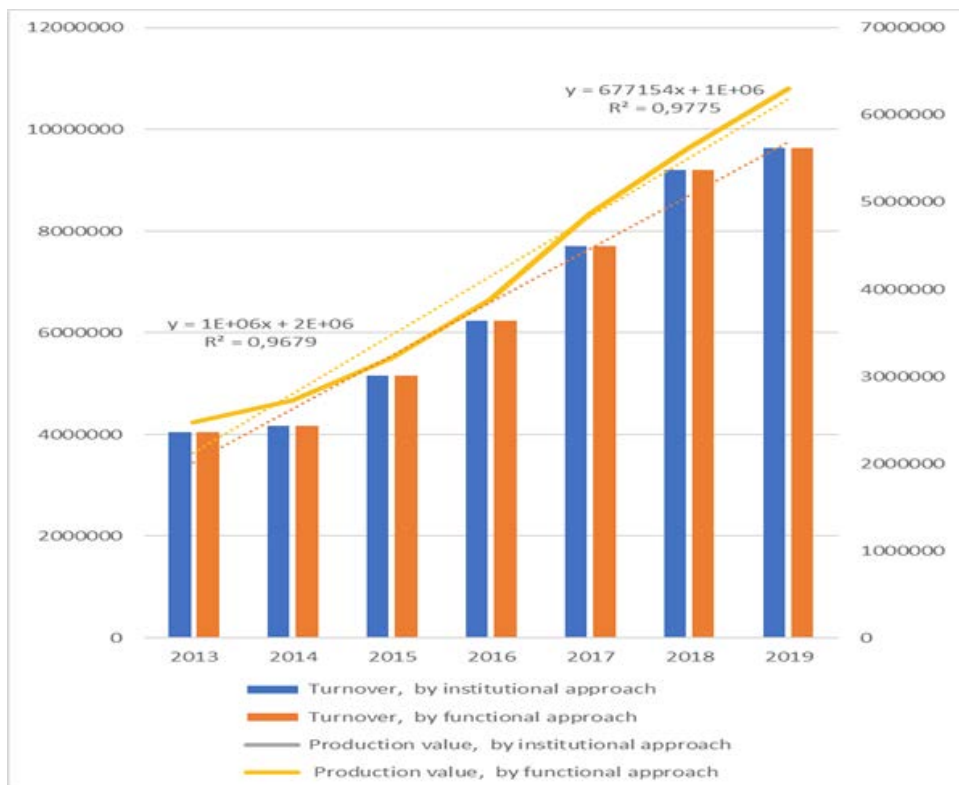

Figure 3: Indicators of enterprises for special aggregates of activities (Commission

Regulation (EC) No. 251/2009 of 11.03.2009) in 2013-2019

Source Calculated according to the State Statistics Service of Ukraine http://ukrstat.gov.ua/

The analysis of indicators of the effectiveness of budget programs was conducted in order to reveal the relationship of accounting and macroeconomic indicators of the development of the agricultural sector of Ukraine. State support is aimed at the development of organizational forms of agricultural enterprises, including small private business, creating conditions for integration, in particular the development of cooperation, equalization of sales conditions through the expansion of the network of wholesale markets, carrying out other support measures - improving the quality of relations with financial and credit system, expanding the access of subjects of agricultural business to the market of financial resources.

Currently, Ukraine has formed a support toolkit that characterizes the focus of budget financing on payments to support production and on financing services (Table 1).

Analysis of the formation of state support for the agricultural sector confirms certain positive shifts in the direction of improving the conditions for providing credit support; purposeful actions in the direction of supporting small commodity producers and strengthening material and technical support through compensation for the cost of machinery and equipment. 
INDEPENDENT JOURNAL OF MANAGEMENT \& PRODUCTION (IJM\&P)

http://www.ijmp.jor.br

v. 12, n. 6, Special Edition ISE, S\&P - November 2021

ISSN: 2236-269X

DOI: $10.14807 /$ ijmp.v12i6.1760

At the same time, it is clearly traced that the envisaged support programs are focused on the introduction of the land market until it is institutionally adopted.

Table 1: Financing of budgetary agricultural programs in 2015-2021, UAH billion

\begin{tabular}{|l|c|c|c|c|c|c|c|}
\hline & 2015 & 2016 & 2017 & 2018 & 2019 & 2020 & 2021 \\
\hline cheap loans & 0,290 & 0,086 & 0,294 & 0,265 & 0,449 & 1,005 & 1,200 \\
\hline support for farmers & - & - & - & 0,048 & 0,416 & 0,032 & 0,200 \\
\hline livestock support & 0,040 & 0,030 & 0,166 & 2,393 & 2,432 & 1,039 & 1,150 \\
\hline $\begin{array}{l}\text { financial support of } \\
\text { commodity } \\
\text { producers }\end{array}$ & - & - & 4,134 & 0,695 & 0,64 & 0,986 & - \\
\hline technical support & & & & & & 1,428 & 1,000 \\
\hline gardening support & - & - & 0,299 & 0,397 & 0,398 & 0,290 & 0,450 \\
\hline other programs & 0,046 & 0,087 & 0,187 & 0,435 & 0,153 & 0,227 & 0,500 \\
\hline Support, total & 0,376 & 0,203 & 5,080 & 4,233 & 4,488 & 3,968 & 4,500 \\
\hline
\end{tabular}

Source: Calculated according to the data of the State Treasury of Ukraine. URL:

https://www.treasury.gov.ua/ua

Along with a proper substantiation of programs to support the development of animal husbandry, horticulture and vegetable growing, the need to introduce financing for agricultural insurance support programs, especially considering the prospects for increasing lending; in support of irrigation given the drastic changes in climatic conditions.

The goal is for all state support programs to generate a positive effect both in the agricultural sector and in the country's economy. So, in the field of state support for the agricultural sector, there is a need both to increase the volume of budgetary financing of the agricultural sector and to improve the institutional framework for its provision by information means.

The diversity of financing over the years shows the lack of an integrated approach to financing agricultural producers, which indicates a lack of certainty of general goals and low efficiency of state regulatory influence. A Resolution of 7.04.21 was adopted, which expands state support for agricultural producers for 2021. In the list of budget programs to support the development of the agricultural sector, they are divided into two parts - existing (the amount of financing for them in 2021 - UAH 4 billion) and new (UAH 500 million), namely: state insurance of agricultural products; support for irrigation in the south; support for organic production; development of potato growing. It is also expected that the adopted the Law on the Land Market No. 2178-10 will make it possible to establish lending secured by land, to create standardized bank credit products for farmers.

The analysis makes it possible to find out a working hypothesis about the dependence of the industry public administration quality from methods of data collection for financial regulation, the formation of a strategy for the development of the industry, the selection of the 
DOI: 10.14807/ijmp.v12i6.1760

structure of programs for state support of commodity producers on the example of budgetary financial regulation of the agricultural sector of Ukraine.

In the stated problem, it should be noted the insufficiency of developments aimed at developing the theory of accounting by improving the methods of its research, for displaying data for the needs of management. Semenyshena (2020) points out on the fact that accounting systems are multi-vector in countries, this caused many misunderstandings and obstacles in the process of generating income from international transactions, became the main driving force of the International Accounting Council (IASB) to create international financial reporting standards (IFRS) on the issues of maintaining high-quality and reliable accounting at enterprises.

The necessary structural analysis of existing scientific approaches and practice of information support of financial support on the example of budget programs in the agricultural sector of the economy, determination of the state and foundations of further development in relation to the financial condition of agricultural enterprises, the level of their accounting and financial reporting, and, accordingly, the awareness of managers to participate in budget programs, filing applications, obtaining budget support and effective use.

Traditionally, accounting is interpreted as an information system, the purpose of which is the collection, systematization, processing and transmission of information. According to Lahovska (2012), accounting is a complex, open, artificial, stochastic, multifunctional, adaptive, dynamic, information and communication system. It also determined that the need to improve accounting processes is an objective reason for improving the management process due to the increase and accumulation of information flows both in medium-sized enterprises and in the external relation of its environment, which requires the need for their synchronization, structuring and selection of a set of relevant data formed in the form accounting message, provides for the use of a systemic and cybernetic approach.

This approach to the development of the fundamental foundations of accounting makes it possible to study in unity the structure of the accounting system (as a conditional static object) and management processes in relation to it and within the framework of the enterprise management system (as a dynamic component). The unity between these components is achieved using accounting information as a connecting link and the main component of their communication interaction. 
DOI: 10.14807/ijmp.v12i6.1760

The institutional environment has recently created the preconditions for a new type of accounting - the social responsibility of entrepreneurship. Some countries, in particular France and England, have introduced legal requirements for mandatory indicators in the field of social reporting. Much attention is paid to the development of analytical systems for collecting and processing information about the state of the environment - the environmental aspects of the enterprise. These relatively new institutions leave an imprint on the basic principles of accounting - while remaining within their framework they complement them with specific ones.

Scientific research of the development of the foundations of the institutional theory of accounting can be carried out according to the following scheme (Fig. 4), based on a systematic approach.

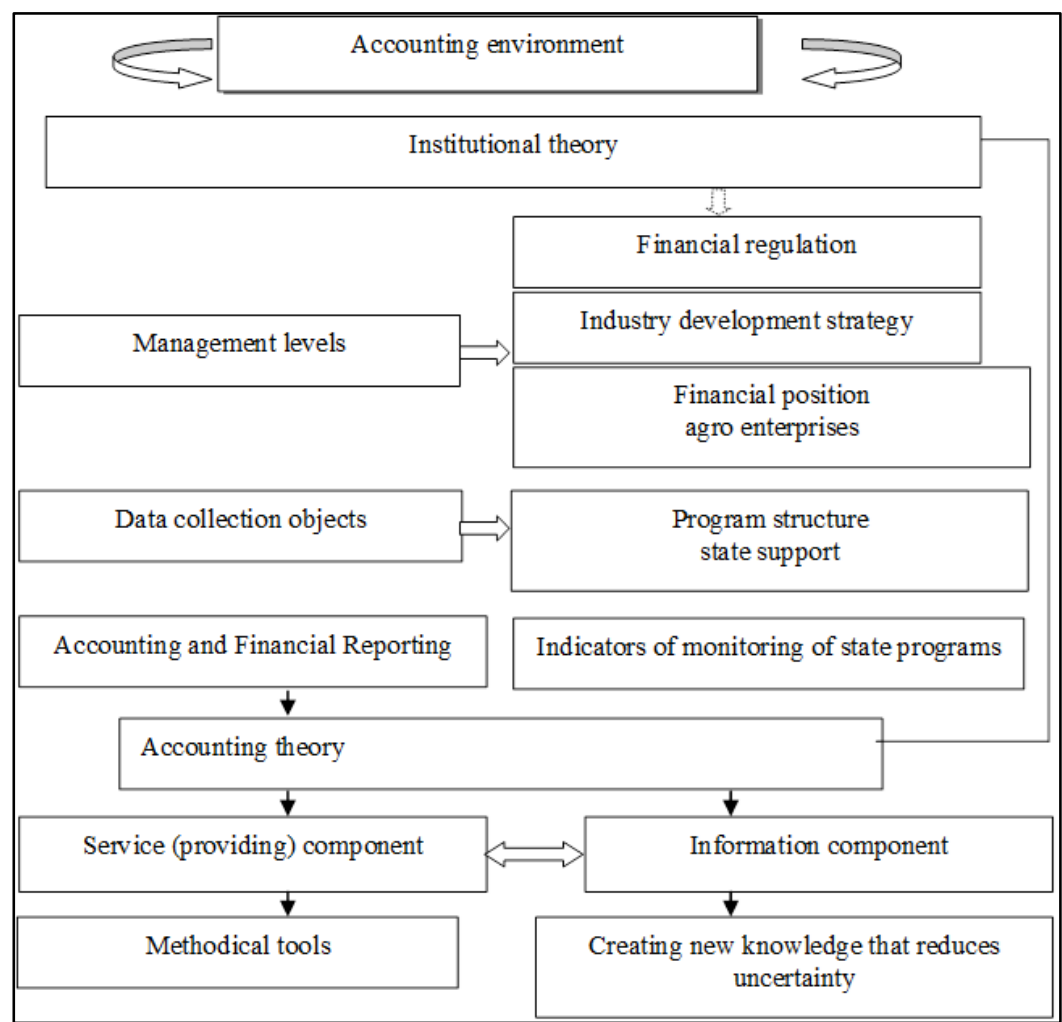

Figure 4: Scheme of the institutional components of accounting to service the management process

Source: The ideas of Semenyshena (2020) are used.

Therefore, first of all, it is necessary to rethink the principle of the function of accounting for information support of management. In this direction the institutional approach makes it possible to introduce into accounting its practical component for the meso and macro levels and to analyse the deep mechanisms of its use. Excessive requirements and overly complex forms of accounting expand the range of methods and tools that distort the balance of 
DOI: $10.14807 /$ ijmp.v12i6.1760

financial and material resources. This is reflected in the ability to realistically assess the financing needs of expanded reproduction in the industry and identify areas that need government support. Therefore, it is important to scientifically substantiate a differentiated approach to institutional changes in the accounting system.

In particular, for modern accounting in accordance with IFRS, traditional indicators of the agricultural sector are becoming less and less adequate indicators of the capital of an enterprise. As a result, as noted by scientists (Semenyshena et al., 2020), the traditional reporting system discloses only simple business transactions - from 1/7 to 1/10 of their value.

The application of the institutional approach should induce the modernization of the paradigm and methodological foundations of accounting. In accounting theory, it is necessary to accelerate the creation of methods for accounting for resources, reserves, assets, costs and expenses, develop new methods for assessing the intangible components of capital and value, move from collecting data on the parameters of institutional units to innovative methods of generating information about institutional links, relationships, transactions, etc. contracts of business entities, including contracts on relations with the budget.

The mechanism of budgetary support depends on subjective factors, it has not been possible to avoid all sorts of abuses, that deepen the inequality of conditions for various forms of management. Lending is more efficient than other programs. Not the least role here is played by information factors - banks independently collect data and form a credit history, reducing their own risks and operating the data necessary for full management. At this level, additional approaches of banks to information manage to implement institutional approaches.

The reason for the incomplete data compliance of accounting with the needs of ensuring the management of financial regulation and the fact that the purpose of accounting for agricultural entrepreneurship is not always reduced to the goals of objectively determining profit, this component is not controlled by external tax services and external audit, since the object of taxation is the land bank. Therefore, accounting is at the discretion of the owners, and simplified accounting cannot provide all the data for a strategic vision of business processes, taking into account the causal links between the vision of economic processes and the role / share of public funding in them

Recommendations on the concentration of state financial resources on key programs of budgetary support for the development of the agricultural sector and improvement of the organizational mechanism for the functioning of the system of budget subsidies in conjunction 
INDEPENDENT JOURNAL OF MANAGEMENT \& PRODUCTION (IJM\&P)

http://www.ijmp.jor.br

v. 12, n. 6, Special Edition ISE, S\&P - November 2021

ISSN: 2236-269X

DOI: $10.14807 /$ ijmp.v12i6.1760

with the achieved financial performance indicators of commodity producers formed in the accounting and information system can be implemented through the assessment of the social and economic effect (Table 2 ) by macro-indicators of the development.

Table 2: Social and economic effect of state support by branches and facilities of the agricultural sector for the period 2015-2019 by macro-indicators of the development

\begin{tabular}{|l|l|l|l|l|l|l|}
\hline Indicators & 2015 & 2016 & 2017 & 2018 & 2019 & $\begin{array}{l}2019 \\
2015, \%,+\end{array}$ \\
\hline Number of business entities, units & 79284 & 74620 & 76593 & 76328 & 75450 & 95,16 \\
\hline $\begin{array}{l}\text { Number of employed persons, } \\
\text { thousand people }\end{array}$ & 2870,6 & 2866,5 & 2860,7 & 2937,6 & 3010,4 & 104,87 \\
\hline $\begin{array}{l}\text { Gross value added (in actual } \\
\text { prices) mln UAH }\end{array}$ & 239806 & 279701 & 303949 & 361173 & 358072 & 149,32 \\
\hline Share of GVA cx,\% & 14,2 & 13,8 & 12,1 & 12,0 & 10,5 & $-3,70$ \\
\hline $\begin{array}{l}\text { Gross domestic product (by } \\
\text { production method), UAH million }\end{array}$ & 558788 & 655569 & 727352 & 871971 & 866138 & 155,00 \\
\hline Agricultural production indices,\% & 95,2 & 106,3 & 97,8 & 108,2 & 101,4 & $+6,20$ \\
\hline $\begin{array}{l}\text { Gross value added per employee } \\
\text { (in 2016 prices) thousand UAH }\end{array}$ & 624 & 765 & 755 & 868 & 928 & 148,72 \\
\hline $\begin{array}{l}\text { The volume of products sold, } \\
\text { UAH million }\end{array}$ & 362309 & 403645 & 454380 & 525096 & 556325 & 153,55 \\
\hline Net profit, UAH mln & 102849 & 90613 & 68858 & 71002 & 93255 & 90,67 \\
\hline $\begin{array}{l}\text { The level of profitability of all } \\
\text { activities,\% }\end{array}$ & 29,5 & 24,7 & 16,0 & 13,7 & 16,1 & $-13,40$ \\
\hline $\begin{array}{l}\text { Capital investments in sg, UAH } \\
\text { mln }\end{array}$ & 30155 & 50484 & 64243 & 66104 & 59130 & 196,09 \\
\hline Specific gravity,\% & 11,0 & 14,1 & 14,3 & 11,4 & 9,5 & $-1,50$ \\
\hline $\begin{array}{l}\text { Consolidated budget expenditures } \\
\text { for cx, UAH billion }\end{array}$ & 5461 & 5479 & 12920 & 13880 & 14401 & 263,71 \\
\hline $\begin{array}{l}\text { Share of agro in budget } \\
\text { expenditures,\% }\end{array}$ & 0,80 & 0,65 & 1,17 & 2,12 & 1,04 & $+0,24$ \\
\hline
\end{tabular}

Source: according to the State Statistics Service of Ukraine http://ukrstat.gov.ua/; Radchenko, Tulush and Hryshchenko (2021)

The main indicators for monitoring the effectiveness of state programs to support the agricultural sector are determined in general, and proposals are made to improve the information support of this process by means of accounting and financial and budget reporting. In particular, some of the requirements for increasing efficiency are already being taken into account - a State Program for the Development of the Agrarian Sector of the Economy until 2030 is being developed, which substantiates the mechanism and tools for the formation of an integral system of budget programs aimed at ensuring the expansion of the range and availability of financial services for agricultural producers. The need for the formation of such programs, by financing current economic activities, expanding credit, leasing and insurance and fund levers as the range of information support and reporting, has been determined.

The choice of the option for the development of institutional accounting theory consists in the grounding of the concepts aimed at maintaining the transparency of public choice, preservation of property rights, participation of capital in expanded reproduction and its share, 
DOI: 10.14807/ijmp.v12i6.1760

formed at the expense of public goods, certain phenomena of agricultural budget expenditures, and the like. So, institutionalism in accounting has formed methods of analysis that are formalized, thereby creating the basis for the genesis of accounting thought, and on the other hand, it proves the importance of creating a unified standardization system that will adequately assess and develop the accounting paradigm.

\section{CONCLUSIONS}

A study of the accounting environment was carried out and proposals were formed to improve its theory for the needs of the macro-level of management from the standpoint of institutional theory. A working hypothesis on the dependence of data collection methods for financial regulation, formation of a strategy for the development of the industry, selection of the structure of programs for state support of commodity producers on the example of budgetary financial regulation of the agricultural sector of Ukraine was confirmed.

The existing scientific approaches and practice of information support of financial support are analysed using the example of budget programs in the agricultural sector of the economy, determination of the state and foundations of further development in connection with the financial condition of agricultural enterprises, the level of their accounting and financial reporting, and, accordingly, the awareness of managers on participation in budget programs, submitting applications, obtaining budgetary support and effective use.

The analysis of indicators of the effectiveness of budget programs was conducted in order to reveal the relationship of accounting and macroeconomic indicators of the development of the agricultural sector of Ukraine.

The methodological approaches to determining the effectiveness of budgetary support for the development of the agro-industrial complex are generalized, a comparative assessment of the effectiveness of various programs of state financial support for agricultural producers is carried out, and statistical material on the state of agriculture is processed. The influence of budget support on the formation of financial indicators of the agricultural sector is determined. Proposals are given on the concentration of state financial resources on key programs of budgetary support for the development of the agricultural sector and the improvement of the organizational mechanism for the functioning of the system of budget subsidies for agricultural producers. The main indicators for monitoring the effectiveness of state programs to support the agricultural sector are determined and proposals are made to improve the information support of this process by means of accounting and financial and budget reporting. 
DOI: $10.14807 /$ ijmp.v12i6.1760

Comparison of the obtained results with the goals and objectives of the study shows that the hypotheses put forward for the choice of priorities for state support, the selection of indicators for assessing the effectiveness, completeness of programs, their compliance with goals and strategies have been implemented. The practical value of the study lies in the fact that the goal is to ensure that all government support programs generate a positive effect both in the agricultural sector and in the country's economy; for this, their social and economic effect is calculated based on information accounting methods.

Prospects for further research within the framework of the stated problem of choosing priorities and the effectiveness of state support for the agrarian sector of Ukraine consist in the need to develop an appropriate methodology for analysing the effectiveness of state support programs based on information methods.

\section{REFERENCES}

Agyekum, A., fua A. B., \& Singh, R. P. (2018). How technology is changing accounting processes: Institutional theory and legitimacy theory perspective. Journal of Accounting and Finance, 18.7, 11-23. DOI: https://doi.org/10.33423/jaf.v18i7.458.

Albu, N., Albu, C. N., \& Gray, S. J. (2020). Institutional factors and the impact of international financial reporting standards: the Central and Eastern European experience. Accounting Forum, 44(3), 184-214. DOI: https://doi.org/10.1080/01559982.2019.1701793.

Balabash, O., Ilin, V., Poprozman, N., Kuznetsova, I., Shushpanov, D., \& Slavina, N. Content Strategy In Management of Communications. Independent Journal of Management \& Production, 12(3), s232-s242. DOI: https://doi.org/10.14807/ijmp.v12i3.1538.

Chaikovskaya, L. A. (2007). Sovremennye koncepcii buhgalterskogo ucheta (teorija i metodologija) [Modern accounting concepts (theory and methodology). Doctoral dissertation] Moskow: Buhgalterskij uchet. (in Russian)

Covaleski, M. A., \& Dirsmith, M. W. (1988). An institutional perspective on the rise, social transformation, and fall of a university budget category. Administrative science quarterly, 33(4), 562-587.

Greenwood R., Suddaby R., \& Hinings C. R. (2002). Theorizing Change: The Role of Professional Associations in the Transformation of Institutionalized Fields. The Academy of Management Journal, 45, 58-80. DOI: https://doi.org/10.2307/3069285.

Grinenko, Ju., Melnychuk, D., Mykhalchyshyna, L., Belei, S., \& Yevtushenko, N. (2021). Improving Transfer Pricing in Ukraine using American Experience. Independent Journal of Management \& Production, 12(3), s205-s231.

DOI: https://doi.org/10.14807/ijmp.v12i3.1524.

Guerreiro, M. S., Rodrigues, L. L., \& Craig, R. (2021). Institutional theory and IFRS: an agenda for future research. Spanish Journal of Finance and Accounting/Revista Española 
INDEPENDENT JOURNAL OF MANAGEMENT \& PRODUCTION (IJM\&P)

http://www.ijmp.jor.br

v. 12, n. 6, Special Edition ISE, S\&P - November 2021

ISSN: 2236-269X

DOI: $10.14807 /$ ijmp.v12i6.1760

de Financiación y Contabilidad, 50.1, 65-88. DOI:

https://doi.org/10.1080/02102412.2020.1712877/.

Guerreiro, R., Pereira, C. A., \& Frezatti, F. (2006). Evaluating management accounting change according to the institutional theory approach: a case study of a Brazilian bank.

Journal of Accounting \& Organizational Change, 2(3), 196-228.

DOI:10.1108/18325910610690063.

Kantsurov, O. O. (2014). Instytutsionalna sehmentatsiia instytutu bukhhalterskoho obliku. [Institutional segmentation of the institute of accounting]. Ahrosvit, (17), 14-20. (in Ukrainian)

Khadaroo, M. I. (2005). An institutional theory perspective on the UK's Private Finance Initiative (PFI) accounting standard setting process. Public Management Review, 7(1), 6994. DOI: https://doi.org/10.1080/1471903042000339428.

Koval, N. I., \& Radchenko, O. D. (2013). Oblikove zabezpechennia upravlinnia finansovoiu diialnistiu ahrarnykh pidpryiemstv [Accounting management of financial activities of agricultural enterprises]. Vinnytsia: PP «TD «Edelveis i K». (in Ukrainian)

Lahovska, O. A. (2012). Systemno-kibernetychnyi pidkhid rozvytku fundamentalnykh zasad bukhhalterskoho obliku. [System-cybernetic approach to the development of fundamental principles of accounting Scientific]. Naukovyi visnyk Uzhhorodskoho universytetu: Seriia: Ekonomika, 2 (36), 296-300. (in Ukrainian)

Lohosha, R., Mykhalchyshyna, L., Prylutskyi, A., \& Kubai, O. (2020). Institutionalization of the agrarian market in Ukraine and European economic community: genesis, evaluation and analysis. Independent Journal of Management \& Production, 11(8), 727-750.

DOI: 10.14807/IJMP.V11I8.1232.

Mishchenko, D. A. (2019). Rozvytok instytutsiinoho mekhanizmu derzhavnoi pidtrymky ahrarnoho sektoru Ukrainy [Development of the institutional mechanism of the state support of the agrarian sector of Ukraine]. Investytsii: praktyka ta dosvid, 68-73. (in Ukrainian)

Nurunnabi, M. (2015). Tensions between politico-institutional factors and accounting regulation in a developing economy: insights from institutional theory. Business Ethics: A European Review, 24(4), 398-424. DOI:10.1111/beer.12089.

Nuzhna, O., Tluchkevych, N., Semenyshena, N., Nahirska, K., \& Sadovska, I. (2019). Making managerial decisions in the agrarian management through the use of ABC-Analysis tool. Independent Journal of Management \& Production, 2019, 10(7). 798-816. DOI: http://dx.doi.org/10.14807/ijmp.v10i7.901.

Pankov, V. V., Kozhuhov, V. L., \& Peshehonov, A. S. (2016). Perspektivy razvitija institucional'noj teorii buhgalterskogo ucheta. [Prospects for the development of the institutional theory of accounting]. Audit, 12, 16-19. (in Russian)

Polenova, S. N. (2012). Institucional'naja model' regulirovanija buhgalterskogo ucheta i otchetnosti v Rossii [Institutional model of accounting and reporting regulation in Russia]. Moscow: Izdatel'sko-torgovaja korporacija «Dashkov i $\mathrm{K}^{0}$ ». (in Russian)

Pozzoli, M., \& Ranucci, S. (2013). The process of implementing the accounting harmonisation in the Italian Local Governments: the case of Prato. International Journal of Business Research and Development, 2(3). DOI:10.24102/ijbrd.v2i3.335

Radchenko, O., Matveyeva, M., Holovanova, H., Makhyboroda, K., \& Haibura, Yu. (2020). Information and Analytical Providion of Budget Support of Institutional Sectors of the 
INDEPENDENT JOURNAL OF MANAGEMENT \& PRODUCTION (IJM\&P)

http://www.ijmp.jor.br

v. 12, n. 6, Special Edition ISE, S\&P - November 2021

ISSN: 2236-269X

DOI: $10.14807 /$ ijmp.v12i6.1760

Economy (on the Example of the Agricultural Sector of Ukraine). Independent Journal of Management \& Production, 11(9), 2355-2378. DOI:

http://dx.doi.org/10.14807/ijmp.v11i9.1418.

Radchenko, O., Melnichuk, O., \& Leontovych, S. (2021). Analysis of the financial share of the national security of Ukraine. In: Yu. Pasichnyk (Ed.) Stages of Formation and

Development of the Economy of Independent Ukraine]. Verlag SWG imex GmbH, Nuremberg, Germany, 3-14. Retrieved from

http://www.aenu.org/download/monographs/Mono2021Germany.pdf.

Radchenko, O., Semenyshena, N., Sadovska, I., Nahirska, K., \& Pokotylska, N. (2020).

Foresight Development Strategy of the Financial Capacity: Comparative Study of the

Ukrainian Agricultural Sector. Engineering Economics, 31(2), 178-187. DOI:

https://doi.org/10.5755/j01.ee.31.2.24340.

Radchenko, O., Tulush, L., \& Hryshchenko, O. (2021). The choice of indicators for monitoring financial regulation of sustainable development of agricultural regions: The example of Ukraine. SHS Web Conf., 106, 01029. DOI:

https://doi.org/10.1051/shsconf/202110601029.

Ribeiro, J. A., \& Scapens, R. W. (2006). Institutional theories in management accounting change: contributions, issues and paths for development. Qualitative research in accounting \& management, 3(July), 94-111. DOI:10.1108/11766090610670640.

Ridder, H. G., Bruns, H. J., \& Spier, F. (2005). Analysis of public management change processes: the case of local government accounting reforms in Germany. Public

administration, 83(2), 443-471. Retrivied from

http://web.worldbank.org/archive/website01531/WEB/IMAGES/ANALYSIS.PDF. Access:

10 July 2021.

Rodrigues, P.C.C., Semenyshena, N. (2021). Editorial Volume 12, Issue 3. Integration System of Education, Science and Production. Independent Journal of Management \& Production, 12(3), s001-s010. DOI: DOI: https://doi.org/10.14807/ijmp.v12i3.1279.

Rodrigues, P.C.C., Simanaviciene, Z., \& Semenyshena, N. (2020). Editorial Volume 11, Issue 9. Independent Journal of Management \& Production, 11(9), 2542-2547. DOI: http://dx.doi.org/10.14807/ ijmp.v11i9.1424.

Sannikova, I. N. (2008). Vozmozhno li preodolet' krizis teorii buhgalterskogo ucheta? [Is it possible to overcome the crisis of accounting theory?]. Accounting in budgetary and nonprofit organizations, (8), 9-12. Retrivied from: https://cyberleninka.ru/article/n/vozmozhnoli-preodolet-krizis-teorii-buhgalterskogo-ucheta. Access: 21 March 2021. (in Russian)

Scapens, R. W., \& Varoutsa, E. (2010). Accounting in inter-organisational relationships: The institutional theory perspective. In H. Hakansson, K. Kraus, \& J. Lind (Eds.), Accounting in networks (314 - 341). Routledge.

Scott, W. R. (2005). Institutional theory: Contributing to a theoretical research program.

Great minds in management: The process of theory development, 37(2), 460-484.

Retrivied from

https://www.researchgate.net/publication/265348080_Institutional_Theory_Contributing_to_ a_Theoretical_Research_Program. Access: 14 July 2021.

Semenyshena, N. V. (2020). Instytutsiinyi pidkhid do rozvytku bukhhalterskomu obliku: realii. [Institutional approach to the development of accounting: realities.]. Retrivied from 
DOI: $10.14807 /$ ijmp.v12i6.1760

https://ir.kneu.edu.ua/bitstream/handle/2010/34938/Oaao_20_12_38.pdf?sequence=1 (in Ukrainian)

Semenyshena, N., Khorunzhak, N., \& Zadorozhnyi, Z.-M. (2020). The institutionalization of accounting: the impact of national standards on the development of economies. Independent Journal of Management \& Production, 11(8), 695-711.

DOI: dx.doi.org/10.14807/ijmp.v11i8.1228

Semenyshena, N., Khorunzhak, N., Lazaryshyna, I., Yurchenko O., \& Ostapenko, Y. (2021). Accounting Institute: on the Genesis and Impact of Management Revolutions. Independent Journal of Management \& Production, 12(3), s243-s261.

DOI: https://doi.org/10.14807/ijmp.v12i3.1540.

Semenyshena, N., Sysiuk, S., Shevchuk, K., Petruk, I., \& Benko, I. (2020). Institutionalism in Accounting: a Requirement of the Times or a Mechanism of Social Pressure? Independent Journal of Management \& Production, 11(9), 2516-2541. DOI: http://dx.doi.org/10.14807/ijmp.v11i9.1440.

Shukalovych, V. F. (2014). Informatsiine zabezpechennia vnutrishnikh instytutiv vertykalnoi intehratsii v ahrobiznesi. [Information support of internal institutions of vertical integration in agribusiness]. Investytsii: praktyka ta dosvid, (23), 47-51.

Sidorova, M. I. (2013). Razvitie modelej buhgalterskogo ucheta v uslovijah sovremennyh informacionnyh tehnologij (dissertacija doktora jekonomicheskih nauk: 08.00.12 Finansovyj un-t pri Pravitel'stve RF) [Doctoral dissertation]. Moscow. (in Russian)

Vdovenko, N., Piven, A., Radchenko, O., Sinenok, I. \& Voskobiinyk, S. (2020). Institutional Environment for Financial Provision of Small Agricultural Business Entities of Ukraine.

Independent Journal of Management \& Production, 11(9), 2379-2402. DOI: http://dx.doi.org/10.14807/ijmp.v11i9.1419.

Vysochan, O. S., \& Yakhvak, D. M. (2017). Instytutsionalizm u suchasnii vitchyznianii teorii bukhhalterskoho obliku: istorychni vytoky ta henezys [Institutionalism in the modern domestic theory of accounting: historical origins and genesis] Prychornomorski ekonomichni studii, 16, 155-161. (in Ukrainian)

Yapa, P. W. S., \& Guah, M. W. (2012). Public-sector accounting and e-governance in developing countries: Case of Sri Lanka. Journal of Asia-Pacific Business, 13(1), 37-58. DOI: https://doi.org/10.1080/10599231.2012.630609.

Zimmerman, A. B., Timothy J. F., \& Gregory, A. J. (2017). Is accounting an applied discipline? An institutional theory assessment of the value of faculty accounting-related work experience in the academic labor market. Journal of Accounting Education, 41, 33-47. DOI: https://doi.org/10.1016/j.jaccedu.2017.09.005. 